\title{
Peningkatan Kemampuan Menulis Berita Melalui Media Gambar Berseri Mahasiswa Tingkat 1 Program Studi Diii Gizi Poltekkes Kemenkes Padang
}

\author{
Ayu Gustia Ningsih, Dwi Christina Rahayuninggrum \\ Sekolah Tinggi Ilmu Kesehatan Seyedza Saintika Padang, Sumatera Barat \\ Email:email: ayugustianingsih@gmail.com, email: noeninksweet@gmail.com
}

\begin{abstract}
Abstrak. Temuan dari hasil wawancara penulis dengan dosen mata kuliah bahasa Indonesia serta mahasiswa tingkat 1 Program Studi D3 Ilmu Gizi Poltekkes Kemenkes Padang adalah, mahasiswa belum mampu menulis berita, karena hal-hal berikut. Pertama kurangnya kemampuan mahasiswa dalam menulis. Kedua, mahasiswa kurang mampu dalam mengembangkan unsur-unsur pembangun sebuah berita. Ketiga, belum efektifnya media pembelajaran yang digunakan dosen. Berdasarkan permasalahan tersebut di atas, penulis pikir penting untuk melaksanakan penelitian tindakan kelas yang bertujuan untuk meningkatkan kemampuan menulis berita dengan media gambar berseri mahasiswa tingkat 1 program studi D3 Ilmu Gizi Poltekkes Kemenkes Padang. Pemilihan media gambar berseri ini dipikir tepat untuk pembelajaran menulis berita, sebab melalui media gambar ini mahasiswa termotivasi karena media dapat diraba, dilihat dan diamati. Selain itu penggunaan media gambar tersebut dipikir mudah dipahami mahasiswa sehingga mahasiswa akan lebih mudah mengungkapkan ide atau gagasannya dalam menulis berita. Kelas ini dipilih karena kemampuan menulis berita dalam belajar rendah jika dibandingkan dengan kelas lain, hal ini dibuktikan dengan perolehan hasil tes menulis karangan eksposisi semester I tahun ajaran $2017 / 2018$. Jenis penelitian ini adalah penelitian tindakan kelas dengan subjek penelitian mahasiswa tingkat 1 Program Studi D III Gizi dengan jumlah mahasiswa 39 orang. Pelaksanaan penelitian dilaksanakan pada semester 2 tahun ajaran 2018/2019. Alat pengumpul data yang digunakan adalah lembar observasi aktivitas mahasiswa dan tes akhir. Teknik analisis data yang digunakan adalah deskriptif dan analisis hasil belajar. Penelitian ini terdiri dari dua siklus dan masing-masing siklus dilakukan dua kali pertemuan. Hasil penelitian pada masing-masing siklus yaitu pra siklus dengan nilai rata-rata mahasiswa 70,87, siklus I dengan nilai rata-rata mahasiswa 86,46 dan siklus II 93,74, hal ini memperlihatkan aktivitas mahasiswa cenderung mengalami peningkatan. Selanjutnya disimpulkan bahwa kuliah pembelajaran menulis berita dengan media gambar berseri dapat meningkatkan aktivitas dan hasil belajar mahasiswa tingkat 1 Program Studi D III Gizi Poltekkes Kemenkes Padang.
\end{abstract}

Kata kunci: Kemampuan Menulis Berita,Media Gambar Berseri

\begin{abstract}
Findings from the results of the author's interviews with Indonesian language lecturers as well as level 1 students of the D3 Nutrition Science Study Program of the Polytechnic of the Ministry of Health in Padang are, students have not been able to write news, because of the following things. First, they have the lack of students' ability in writing. Second, students are less able to develop the elements of building news. Third, ineffective learning media used by lecturers. Based on the aforementioned problems, the authors think it is important to carry out classroom action research aimed at improving the ability to write news with serial images of students of level 1 of the D3 Nutrition Science program at the Health Ministry of Health in Padang. The selection of this serial image media is thought to be appropriate for learning to write news, because through this image media students are motivated because the media can be touched, seen and observed. In addition, the use of image media is thought to be easy for students to understand so students will more easily express their ideas or ideas in writing news. This class was chosen because the ability to write news in learning is low when compared to other classes, this is evidenced by the acquisition of the results of the writing test exposition of semester I of the academic year 2017/2018. The type of this research is classroom action research with the research subject level 1 of the Nutrition D III Study Program with 39 students. The research was carried out in semester 2 of the 2018/2019 school year. Data collection tools used were student activity observation sheets and final tests. Data analysis techniques used are descriptive and analysis of learning outcomes. This research consisted of two cycles and each cycle was held twice. The results of the study in each cycle are pre-cycle with an average value of 70.87 students, the first cycle with an average value of 86.46 students and the second cycle 93.74, this shows student activity tends to increase. Furthermore, it was concluded that lectures on learning to write news with serial image media can increase the activity and learning outcomes of students in level 1 of the D III Nutrition Study Program of the Health Ministry of Health in Padang.
\end{abstract}

Keywords: Ability to Write News, Media of Picture Series

\section{PENDAHULUAN}

Perkuliahan bahasa Indonesia di perguruan tinggi bertujuan untuk menumbuhkembangkan kemampuan berbahasa mahasiswa. Terampil berbahasa berarti terampil dalam menyimak, berbicara, membaca, dan menulis. Kemampuan menulis sebagai salah satu ketrampilan berbahasa yang bersifat produktif sangat penting bagi mahasiswa. Mahasiswa diharapkan mampu mengungkapkan ide, gagasan, pengalaman, dan pendapat dalam berbagai bentuk tulisan.

Kurikulum yang digunakan untuk program studi D3 Ilmu Gizi Poltekkes Kemenkes Padang berdasarkan keputusan Menteri Pendidikan dan Kebudayaan Republik Indonesia Nomor 73/U/2913 adalah 
Kurikulum KKNI. Mata kuliah Bahasa Indonesia diajarkan pada semerter 1, beban studi 2 sks metode teori. Berdasarkan buku pedoman akademik Program Studi D3 Ilmu Gizi Poltekkes Kemenkes Padang pada tahun 2017 maka mata kuliah bahasa Indonesia diajarkan sesuai dengan silabus yang dirancang berdasarkan kurikulum. Mahasiswa diharapkan mampu menulis berita. Untuk menuliskan sebuah berita, maka diperlukan struktur pengembangan, yakni $5 \mathrm{~W}+1 \mathrm{H}$ yaitu: What (apa), Who (siapa), When (kapan), Why (mengapa), Where (dimana), dan How (bagaimana).

Temuan dari hasil wawancara penulis dengan dosen mata kuliah bahasa Indonesia serta mahasiswa tingkat 1 Program Studi D3 Ilmu Gizi Poltekkes Kemenkes Padang adalah, mahasiswa belum mampu menulis berita, karena hal-hal berikut. Pertama kurangnya kemampuan mahasiswa dalam menulis. Kedua, mahasiswa kurang mampu dalam mengembangkan unsur-unsur pembangun sebuah berita. Ketiga, belum efektifnya media pembelajaran yang digunakan dosen.

Berdasarkan permasalahan tersebut di atas, penulis pikir penting untuk melaksanakan penelitian tindakan kelas yang bertujuan untuk meningkatkan kemampuan menulis berita dengan media gambar berseri mahasiswa tingkat 1 program studi D3 Ilmu Gizi Poltekkes Kemenkes Padang. Pemilihan media gambar berseri ini dipikir tepat untuk pembelajaran menulis berita, sebab melalui media gambar ini mahasiswa termotivasi karena media dapat diraba, dilihat dan diamati. Selain itu penggunaan media gambar tersebut dipikir mudah dipahami mahasiswa sehingga mahasiswa akan lebih mudah mengungkapkan ide atau gagasannya dalam menulis berita.

Kelas ini dipilih karena kemampuan menulis berita dalam belajar rendah jika dibandingkan dengan kelas lain, hal ini dibuktikan dengan perolehan hasil tes menulis karangan eksposisi semester I tahun ajaran 2017/2018 seperti pada tabel di bawah ini:

Tabel 1. Rata-rata nilai tugas menulis berita tahun 2017/2018 di Poltekkes Kemenkes Padang

\begin{tabular}{cccc}
\hline Prodi & Nilai Rata- Rata & Jumlah mahasiswa yang lulus & Jumlah mahasiswa yang tidak lulus \\
\hline D3 Kebidanan & 72 & 26 & 4 \\
D4 Ilmu Gizi & 69 & 24 & 6 \\
D3 Ilmu Gizi & 66 & 21 & 9 \\
\hline
\end{tabular}

Sumber: Nilai tes kemampuan menulis karangan berita mata kuliah bahasa Indonesia semester ganjil th 2017/2018

Agar kemampuan menulis mahasiswa meningkat maka dosen berusaha untuk mencari solusi dari permasalahan ini dengan melakukan sebuah penelitian tidakan kelas yang berjudul "Peningkatan Kemampuan Menulis Berita melalui Media Gambar Berseri Mahasiswa Tingkat 1 Program Studi D3 Ilmu Gizi Poltekkes Kemenkes Padang”.

Penelitian ini bertujuan untuk mendeskripsikan dan menjelaskan proses peningkatan kemampuan menulis berita melalui media gambar berseri bagi mahasiswa tingkat 1 Program Studi D3 Ilmu Gizi Poltekkes Kemenkes Padang. Tahapan Metode Penelitian Tindakan Kelas yang akan dilakukan bisa dilihat pada gambar di bawah.

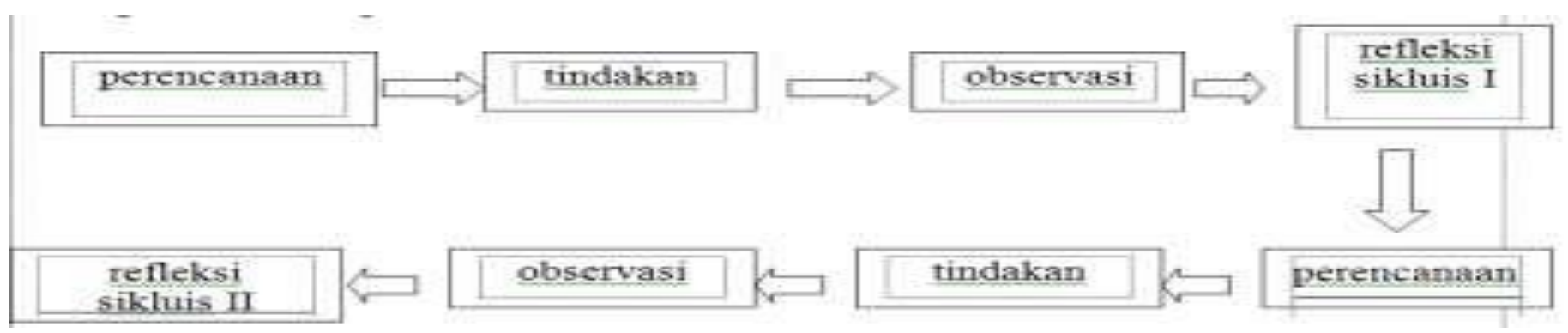

Gambar 1. Tahapan Metode Penelitian Tindakan Kelas

Bertolak dari latar belakang maka rumusan penelitiannya adalah sebagai berikut. "Apakah Media Gambar Berseri dapat Meningkatkan Kemampuan Menulis Berita Mahasiswa Tingkat 1 Program Studi D III Ilmu Gizi Poltekkes Kemenkes Padang?

Menurut Gie (2002:3) pengertian menulis, tulisan, penulis, dan tulis-menulis adalah sama seperti pengertian mengarang, karangan, pengarang dan karang-mengarang yang telah diberikan batasannya. 
Hanya pada batasan menulis berkembang suatu kata yang tidak ada timpalannya pada kata mengarang yaitu kata "penulisan". Penulisan berarti proses, kegiatan atau cara menulis, misalnya penulisan berita berarti proses menulis berita, kegiatan menulis berita atau cara menulis berita.

Menurut Harris dalam Yondri (2006:14) seorang penulis harus menguasai lima komponen tulisan, yaitu: isi (materi) tulisan, organisasi tulisan, kebahasaan (kaedah bahasa tulis), gaya penulisan, dan mekanisme tulisan. Kegagalan dalam salah satu komponen dapat mengakibatkan gangguan dalam menuangkan ide secara tertulis.

Mengacu kepada pemikiran di atas, jelaslah bahwa menulis bukan hanya sekedar menuliskan apa yang diucapkan (membahasa tuliskan bahasa lisan), tetapi merupakan suatu kegiatan yang terorganisir sedemikian rupa sehingga terjadi suatu tindak komunikasi (antara penulis dengan pembaca). Bila apa yang dimaksudkan oleh pembaca, maka seseorang dapat dikatakan telah terampil menulis.

Barus (2016:12) mengatakan "Berita adalah segala laporan mengenai peristiwa, kejadian, gagasan, fakta yang menarik perhatian dan penting untuk disampaikan atau dimuat dalam media massa agar diketahui atau menjadi kesadaran umum". Sejalan dengan hal itu, Oramahi (2012:2) mengemukakan "Berita adalah suatu informasi baru (new) yang mengandung makna penting (significant), memiliki pengaruh terhadap siapapun yang mendengar atau membacanya, dan menarik bagi si pendengar (radio), pemirsa (televisi), dan pembaca (media cetak). Berita merupakan objek kajian jurnalistik yang mempunyai bagian-bagian tersusun secara sistematis. Bagian tersebut yaitu head line (judul berita), lead (teras berita), dan body (tubuh berita) dikemukakan oleh Ermanto (2001:90).

Teras berita merupakan bagian terpenting dalam sebuah berita. Dalam teras berita dipaparkan kejadian yang terjadi dan terdapat enam unsur pembangun dari sebuah berita. Adapun enam unsur-unsur berita, yaitu, 1) peristiwa apa yang terjadi, 2) siapa terlibat, 3) kapan terjadi, 4) dimana tempatnya, 5) bagaimana kejadiannya, dan 6) mengapa terjadi. Tradisi jurnalistik telah lazim mengenal keenam unsur ini dengan $5 \mathrm{~W}+1 \mathrm{H}$ : what, who, when, where, why, dan how.

Assegaf (1991:49) menyatakan dalam memenuhi persyaratan bentuk hendaknya memperhatikan gaya penulisan piramida terbalik, seperti pada gambar dibawah ini, :

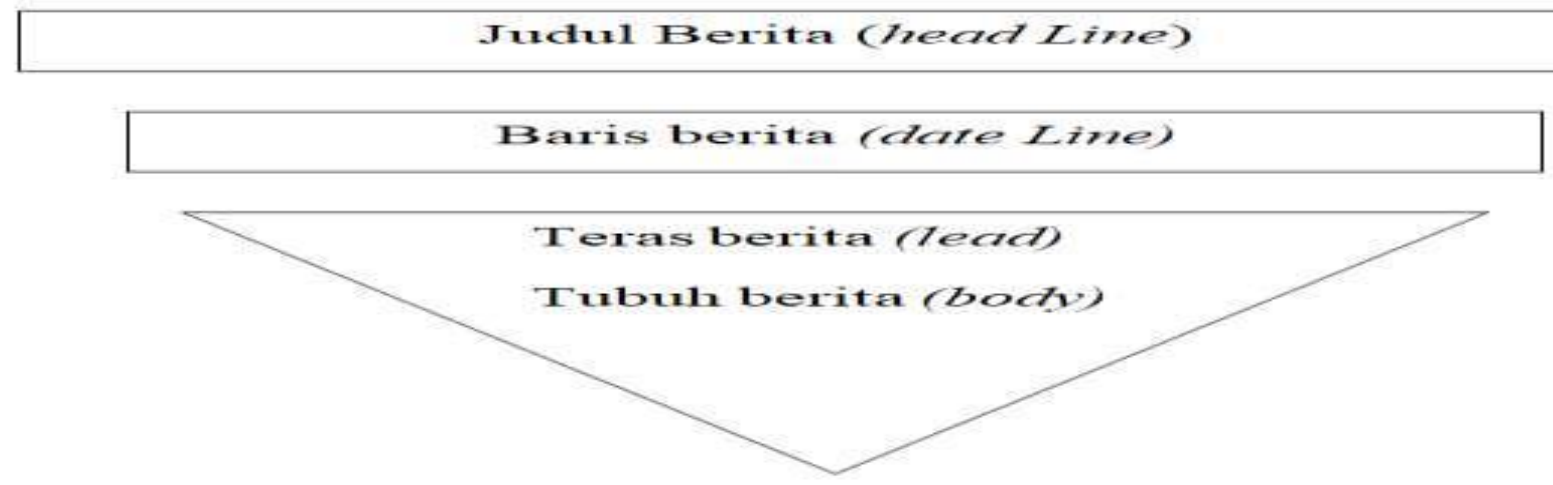

Gambar 2. Gaya Penulisan Berita

Gambar merupakan salah satu bentuk media dalam pengajaran bahasa Indonesia. Menurut Suyatno (2004:81) dari gambar mahasiswa dapat membuat tulisan secara runtut dan logis. Selanjutnya Sardiman (2009:29) media gambar memiliki kelebihan yaitu:

1) sifatnya konkret,

2) gambar dapat mengatasi batasan ruang dan waktu,

3) media gambar dapat mengatasi keterbatasan pengamatan,

4) gambar dapat memperjelas suatu masalah dalam bidang apa saja dan untuk tingkat usia berapa saja, sehingga dapat mencegah atau membetulkan kesalahpahaman,

5) gambar harganya murah dan gampang didapat serta digunakan tanpa memerlukan peralatan khusus.

Selain memiliki kelebihan, media gambar juga memiliki kelemahan di antaranya :

a) gambar hanya menekankan persepsi indera mata, 
b) gambar benda yang terlalu kompleks kurang efektif untuk kegiatan perkuliahan,

c) ukurannya sangat terbatas untuk ukuran besar

\section{METODE PENELITIAN}

Jenis penelitian ini adalah penelitian tindakan kelas ( classroom action research) yang dikembangkan oleh Kemmis dan Mc. Taggrart dalam Arikunto (2006) yaitu melalui siklus yang terdiri dari; planning, acting, observing dan reflecting ( perencanaan, pelaksanaan, observasi, dan refleksi). Arikunto (dalam Ningsih 2013:6) menyimpulkan kalau penelitian tindakan kelas adalah suatu pencermatan terhadap kegiatan yang belajar berupa sebuah tidakan, yang sengaja dimunculkan dan terjadi dalam sebuah kelas secara bersama. Merujuk pada media di atas maka penelitian tindakan kelas ini dilaksanakan dengan 2 siklus. Siklus kedua merupakan penyempurnaan dari siklus sebelumnya, untuk itu dapat digambarkan seperti dibawah ini :

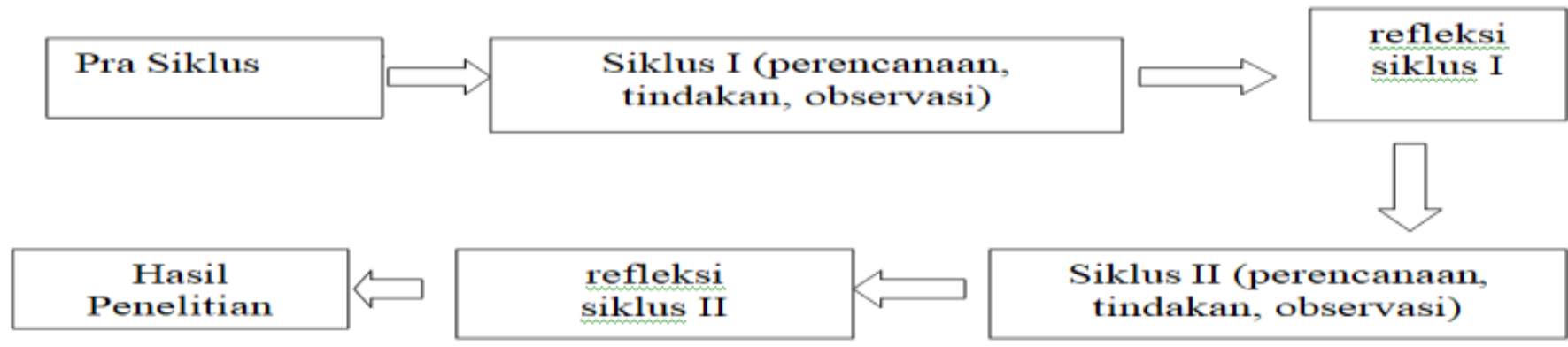

Gambar 3. Siklus Penelitian

Penelitian ini akan dilaksanakan di Poltekkes Kemenkes Padang. Subjek penelitian adalah mahasiswa tingkat 1 Program Studi D3 Ilmu Gizi dengan jumlah mahasiswa 39 orang. Pelaksanaan penelitian dilaksanakan pada semester 1 tahun ajaran 2018/2019.

\section{Langkah-langkah \\ Perencanaan terdiri atas}

1. merancang skenario perkuliahan, hal ini dilakukan oleh penelitil dan peneliti

2. menyiapkan bahan ajar sesuai dengan indikator yang akan dibahas

3. menyiapkan lembaran kerja mahasiswa (gambar berseri)

4. menyiapkan instrument pengamatan

5. menyususun lembaran penilaian

\section{Pelaksanaan terdiri dari atas}

Melaksanakan perkuliahan sesuai dengan skenario perkuliahan yang telah dipersiapkan (dilaksanakan oleh peneliti 1 dan 2 dibantu operator) dengan langkah- langkah sebagai berikut ini,

1. Pendahuluan

a. Apersepsi, tanya jawab dengan mahasiswa tentang pelajaran yang lalu

b. Motivasi, dosen menampilkan dan membacakan salah satu berita yang ditulis mahasiswa pada kegiatan yang lalu

2. Kegiatan Inti
a. Mahasiswa dan dosen tanya jawab tentang berita
b. Dosen memajang gambar berita yang lain di papan tulis
c. Dosen meminta mahasiswa mengemukakan kesulitan-kesulitan dan kemudahan dalam menulis berita dengan media gambar lalu mendidiskusikannya dan mencari solusinya
d. Mahasiswa mengamati gambar
e. Dosen menjelaskan unsur-unsur pembangun berita $(5 \mathrm{~W}+1 \mathrm{H})$
f. Mahasiswa mengidentifikasi sebuah fakta yang ditemukan pada gambar
g. Dosen menuruh mahasiswa menulis berita dengan mengembangkan unsure $(5 \mathrm{~W}+1 \mathrm{H})$ berdasarkan gambar yang diberikan oleh dosen 
h. Mahasiswa merevisi kalimat yang dibuat sesuai dengan penggunaan unsure $(5 \mathrm{~W}+1 \mathrm{H})$

i. Dosen mengumpulkan pekerjaan mahasiswa dan menampilkan salah satu dari pekerjaan mahasiswa tersebut serta mendiskusikan penggunaan unsur $5 \mathrm{~W}+1 \mathrm{H}$ dan kesesuain isi dengan gambar

3. Penutup

a. Dosen mengklarifikasi hasil kerja mahasiswa

b. Dosen bersama mahasiswa menyimpulkan pelajaran

c. Dosen merefleksi tentang kegiatan perkuliahan

\section{Observasi terdiri dari atas}

1. Melakukan pengamatan tentang kemampuan menulis berita mahasiswa

2. Mendokumentasikan kegiatan-kegiatan yang menonjol selama proses perkuliahan

\section{Refleksi terdiri dari atas}

1. Meminta balikan pada mahasiswa diakhir perkuliahan tentang kegiatan yang telah dilakukan

2. Menganalisis hasil pengamatan

3. Mengidentifikasi kelemahan-kelemahan yang ditemui

4. Mempersiapkan rencana tindakan baru untuk pertemuan berikutnya.

5. Kesalahan-kesalahan kecil yang ditemui diperbaiki.

\section{Teknik Pengumpulan data}

Untuk pengumpulan data, maka dipakailah panduan observasi yang sudah disusun disaat perencanaan untuk melihat kemampuan menulis berita terhadap aktivitas belajar mahasiswa melalui gambar berseri. Tes digunakan untuk melihat hasil belajar mahasiswa dari kemampuan menulis berita melalui gambar berseri.

\section{Alat Pengumpulan data}

Alat pengumpul data adalah lembaran observasi yang dilakukan oleh observer di saat perkuliahan terhadap aktivitas perkuliahan media gambar berseri, dan Tes digunakan untuk melihat hasil belajar mahasiswa dari kemampuan menulis berita melalui gambar berseri.

Dalam penelitian ini data dianalisis secara deskriptif kualitatif dan dilakukan secara rasional dan objektif.

Teknik mengukur aktivitas mahasiswa dalam belajar dianalisis dengan menggunakan rumus:

$$
\begin{array}{ll}
\mathrm{P} & =\mathrm{F} \times 100 \% \mathrm{~N} \\
\mathrm{P} & =\text { Presentase } \\
\mathrm{F} & =\text { Frekuensi aktivitas mahasiswa } \\
\mathrm{N} & =\text { Jumlah responden (Sudjana.1991) }
\end{array}
$$

Peningkatan aktivitas mahasiswa dalam proses belajar mengajar dapat dilihat dengan membandingkan observasi siklus I dan observasi siklus II. Indikator keberhasilan untuk menulis berita telah ditetapkan di awal semester yaitu 75. Apabila ada mahasiswa yang tidak mencapai 68, maka mahasiswa dinyatakan gagal

\section{HASIL DAN PEMBAHASAN}

Pelaksanaan penelitian tindakan terhadap Kemampuan Menulis Berita melalui Media Gambar Berseri Mahasiswa Tingkat 1 Program Studi D3 Ilmu Gizi Poltekkes Kemenkes Padang dilakukan dalam dua siklus. Pelaksanaan kedua siklus tersebut, berlangsung dari tanggal 25 April-09 Mai 2019. Setiap siklus berlangsung satu kali pertemuan. Pelaksanaan siklus I dan siklus II berpedoman pada temuan yang terdapat pada prasiklus. Uraian berikut merupakan proses yang terjadi selama pelakasanaan proses kemampuan menulis.

Setelah dilakukan tes kemampuan awal menulis berita kepada mahasiswa Tingkat 1 Program Studi D3 Ilmu Gizi Poltekkes Kemenkes Padang diperoleh hasil berikut ini. 
Ayu Gustia Ningsih \& Dwi Christina Rahayuninggrum, Peningkatan Kemampuan Menulis Berita Melalui Media Gambar Berseri Mahasiswa Tingkat 1 Program Studi Diii Gizi Poltekkes Kemenkes Padang

Tabel 2. Hasil Penilaian Tes Kemampuan Awal Menulis

\begin{tabular}{llll}
\hline \multirow{2}{*}{ Prasiklus } & $\begin{array}{l}\text { Persentase dan Jumlah Mahaiswa yang } \\
\text { Mencapai Nilai } \geq 75\end{array}$ & $\begin{array}{l}\text { Persentase Jumlah Mahasiswa yang Mencapai } \\
\text { Nilai } \leq 75\end{array}$ & \multirow{2}{*}{ Rata-rata Nilai } \\
\hline \multirow{2}{*}{ I } & 14 orang & $\begin{array}{c}25 \text { orang } \\
(64,10 \%)\end{array}$ & 70,87 \\
\hline
\end{tabular}

Berdasarkan tabel di atas terlihat bahwa hasil tes kemampuan awal (prasiklus) mahasiswa yang memperoleh nilai lebih dari 75 hanya $(35,90 \%)$ mahasiswa, sedangkan $(64,10 \%)$ mahasiswa belum mencapai kriteria ketuntasan minimal. Berarti, lebih dari setengah jumlah mahasiswa belum mencapai kriteria ketuntasan minimal. Banyaknya mahasiswa yang belum mencapai kriteria ketuntasan minimal 75 karena mahasiswa masih banyak menggunakan penulisan judul yang masih kurang menarik, dan belum lengkap menuliskan unsur-unsur berita, kalimat yang digunakan dalam menulis berita masih belum semuanya yang efektif. Penerapan ejaan bulum dilakukan secara baik, serta koherensi antar paragraf masih perlu diperbaiki kembali. Dosen lebih banyak mengajar daripada membelajarkan mereka. Dengan perkataan lain, siswa mendengar, kemudian menulis tentang apa yang diperintahkan dosen. Dari Tabel 3 tersebut, juga terlihat bahwa kemampuan menulis siswa secara klasikal 70,87.

Berdasarkan data di atas, dapat dinyatakan bahwa perkuliahan pada waktu prasiklus tidak berjalan secara optimal, sehingga perlu dilakukan suatu upaya dengan melaksanakan penelitian tindakan. Upaya tersebut adalah untuk meningkatkan kemampuan menulis melalui media gambar berseri.

Tindakan pada siklus I dilaksanakan satu kali pertemuan sesuai dengan rencana yang telah dibuat. Data hasil tindakan pada siklus I berupa hasil tes kinerja terlihat pada tabel di bawah ini.

Tabel 3. Hasil Penilaian Tes Kemampuan Awal Menulis

\begin{tabular}{llll}
\hline \multirow{2}{*}{ Prasiklus } & $\begin{array}{l}\text { Persentase dan Jumlah Siswa yang } \\
\text { Mencapai Nilai } \geq 75\end{array}$ & $\begin{array}{l}\text { Persentase Jumlah Siswa yang } \\
\text { Mencapai Nilai } \leq 75\end{array}$ & Rata-rata Nilai \\
\hline \multirow{2}{*}{$\mathrm{I}$} & $\begin{array}{l}14 \text { orang } \\
(35,90 \%)\end{array}$ & $\begin{array}{l}25 \text { orang } \\
(64,10 \%)\end{array}$ & $70,87 \%$ \\
\hline
\end{tabular}

Tabel 4. Hasil Tindakan pada Siklus I

\begin{tabular}{llll}
\hline \multirow{2}{*}{ Siklus } & $\begin{array}{l}\text { Persentase dan Jumlah Siswa yang Mencapai Nilai } \\
\geq 75\end{array}$ & $\begin{array}{l}\text { Persentase dan Jumlah Siswa yang Mencapai } \\
\text { Nilai } \leq 75\end{array}$ & $\begin{array}{l}\text { Rata-rata } \\
\text { Nilai }\end{array}$ \\
\hline \multirow{2}{*}{ I } & $\begin{array}{l}38 \text { orang } \\
(97,4 \%)\end{array}$ & $\begin{array}{l}1 \text { orang } \\
(2,6 \%)\end{array}$ & $86,46 \%$ \\
\hline
\end{tabular}

Tabel 5. Hasil Tindakan pada Siklus II

\begin{tabular}{cccc}
\hline \multirow{2}{*}{ Siklus } & Persentase dan Jumlah Siswa yang Mencapai & Persentase dan Jumlah Siswa yang Mencapai & Rata-rata \\
& Nilai $\geq 75$ & Nilai $\leq 75$ & Nilai \\
\hline \multirow{2}{*}{ II } & 39 orang & 0 orang & $93,74 \%$ \\
& $(100 \%)$ & $(0 \%)$ & 9 \\
\hline
\end{tabular}

Tabel 6. Hasil Tindakan Kemampuan Menulis

\begin{tabular}{cccccc}
\hline \multicolumn{2}{c}{ Kemampuan Awal } & \multicolumn{2}{c}{ Siklus I } & \multicolumn{2}{c}{ Siklus II } \\
Ketuntasan & Ketuntasan & \multicolumn{2}{c}{ Ketuntasan } \\
Ya & Tidak & Ya & Tidak & Ya & Tidak \\
\hline 14 siswa & 25 siswa & 38 siswa & 1 siswa & 39 siswa & 0 siswa \\
$35,9 \%$ & $64,1 \%$ & $97,4 \%$ & $2,6 \%$ & $100 \%$ & $0 \%$ \\
\hline
\end{tabular}

Hasil tindakan pada siklus II secara umum meningkatkan aktivitas siswa dalam perkuliahan. Pada pertemuan siklus pertama, aktivitas siswa dalam perkuliahan rata-rata $(73 \%)$ meningkat pada pertemuan siklus kedua menjadi $(84,6 \%)$. Hasil ini membuktikan bahwa siswa telah memiliki persepsi bahwa gambar berseri dapat meningkatkan kemampuan menulis, sehingga aktivitas perkuliahan meningkat. Aktivitas terendah $(74,36 \%)$ keaktifan dalam bertanya. Hasil ini disebabkan oleh faktor materi perkuliahan yang lebih menuntut mahasiswa untuk banyak menulis. 


\section{SIMPULAN}

Sebagaimana dikemukakan pada bagian pendahuluan, tujuan penelitian ini adalah untuk membuktikan apakah kemampuan menulis berita mahasiswa Tingkat 1 Prodi D III Gizi Poltekkes Kemenkes Padang dapat ditingkatkan melalui penggunaan media gambar berseri dalam pembelajaran atau tidak.

Keterampilan mahasiswa dalam menulis dapat ditingkatkan melalui penggunaan media gambar berseri. Hasil tes awal, didapatkan data kemampuan menulis berita mahasiswa kurang baik. Setelah diberikan tindakan berupa penggunaan media gambar berseri dan pemantapan dalam proses pembelajaran dalam dua siklus, ternyata tindakan yang dilakukan itu berdampak pada peningkatan keterampilan menulis dan sikap mahasiswa dalam pembelajaran lebih baik.

Berdasarkan penelitian yang telah dilakukan, diperoleh hasil bahwa penggunaan media gambar berseri dalam pembelajaran menulis berita dapat meningkatkan kemampuan mahasiswa dalam menulis, khususnya menulis berita. Kesignifikan itu terlihat dari data hasil tes awal yang kurang baik, setelah pemberian tindakan, hasil tes siklus I meningkat pada siklus II. Di samping itu, penggunaan media gambar berseri juga dapat meningkatkan sikap dan perilaku positif mahasiswa dalam proses pembelajaran menulis berita.

\section{DAFTAR PUSTAKA}

Gie, The Liang. 2002. Terampil Mengarang. Yokyakarta: Andi.

Suparno. 2008. Ketrampilan Dasar Menulis. Jakarta : UT Depdiknas.

Yondri. 2006. Peningkatan Ketrampilan Menulis Paragraf melalui Pendekatan Kontekstual. Padang:Jurnal Pendidikan Sumatra Barat.

Barus, S. W.. 2016. Jurnalistik Petunjuk Teknik Menulis Berita, Jakarta: Erlangga.

Asyari, Hasan Oramahi. 2012. Jurnalistik Radio:Kiat Menulis Berita Radio. Jakarta: Erlangga.

Ermanto. 2001. "Berita dan Fotografi" . Buku Ajar. Padang:FBSS UNP.

Hartati, Sri. 2015. "Peningkatan Kemampuan Menulis Berita dengan Pendekatan Terpadu dan Media Gambar pada siswa Kelas VIII SMP Negeri 1 Teras" dalam Jurnal Manajemen Pendidikan. Vol 10. No.2. Juli 2015. https://media.neliti.com. Diunduh pada10 September 2018.

Amalia, Zafruf. 2013. "Peningkatan Kemampuan Menulis Teks Berita melalui Media Foto Peristiwa pada Peserta Didik Kelas VIIIA SMP N 5 Pekalongan Tahun Ajaran 2012/2013" Skripsi. Universitas Negeri Semarang. http://lib.unnes.ac.id. Diunduh tanggal 10 September 2018.

Sanjaya, Wina. 2009. Strategi Perkuliahan. Jakarta: Prenada Media Grup.

Suyatno. 2009. Teknik Perkuliahan dan Sastra. Surabaya: SIC.

Sardiman. Arif S. 2007. Media Pendidikan. Jakarta:Raja Grafindo Persada.

Arikunto, Suharsimi. 2006. Penelitian Tindakan Kelas. Jakarta: Bumi Aksara.

Ningsih, Ayu Gustia. 2013. "Peningkatan Keterampilan Berbicara melalui Media Gambar berseri Siswa Kelas X MAS-TI Tabek Gadang Kabupaten Lima Puluh Kota" dalam Jurnal Bahasa, Sastra dan Perkuliahan $\quad$ Volume $\quad 1 \quad$ Nomor $\quad 3 \quad$ Oktober 2013.http://ejournal.unp.ac.id/index.php/bsp/article/download/5007/3959. Diunduh tanggal 23 April 2019. 